\title{
Cytotoxicity and osteogenic potential of experimental medication with calcium
}

\section{hydroxide and activated charcoal}

\author{
Citotoxicidade e potencial osteogênico de medicação experimental com hidróxidlo de cálcio e carvão \\ ativado
}

Citotoxicidad y potencial osteogénico de la medicación experimental con hidróxido de calcio y carbón activado

Received: 04/05/2021 | Reviewed: 04/15/2021 |Accept: 04/20/2021 | Published: 06/05/2021

\author{
Gabriela Sumie Yaguinuma Gonçalves \\ ORCID: https://orcid.org/0000-0001-5120-3172 \\ São Paulo State University Júlio de Mesquita Filho, Brazil \\ E-mail: gabisumie@ hotmail.com \\ Danielle Gregorio \\ ORCID: https://orcid.org/0000-0002-0098-624X \\ Universidade Pitágoras UNOPAR, Brazil \\ E-mail: daanigregorio@hotmail.com \\ Isabelly Ribeiro Custódio \\ ORCID: https://orcid.org/0000-0002-0859-4822 \\ Universidade Pitágoras UNOPAR, Brazil \\ E-mail: isabelly.rc@gmail.com \\ Luciana Prado Maia \\ ORCID: https://orcid.org/0000-0001-5697-2587 \\ Universidade Pitágoras UNOPAR, Brazil \\ E-mail: lucianapmaia@gmail.com \\ Bruno Piazza \\ ORCID: https://orcid.org/0000-0001-8975-1545 \\ Universidade do Oeste Paulista, Brazil \\ E-mail: brunopiazza@unoeste.br \\ Graziela Garrido Mori \\ ORCID: https://orcid.org/0000-0002-8690-5294 \\ Universidade do Oeste Paulista, Brazil \\ E-mail: graziela@unoeste.br
}

\begin{abstract}
Objectives: The aim of this study was to evaluate the cytotoxicity and osteogenic potential of experimental medications containing Calcium Hydroxide $(\mathrm{CH})$ and Activated charcoal (AC). Methodology: Osteoblastic (MC3T3) and fibroblastic (L929) cells were cultivated in 96 well plates $\left(1 \times 10^{4}\right.$ cells/well) and, after $24 \mathrm{~h}$, treated with extracts, according to experimental groups [(Experimental groups: $\mathrm{C}-\mathrm{Control}$; $\mathrm{CH}-\mathrm{CH}$ paste; $\mathrm{CH}+10 \% \mathrm{AC}-$ experimental paste $1(\mathrm{CH}$ paste $+10 \% \mathrm{AC}) ; \mathrm{CH}+5 \% \mathrm{AC}$ - experimental paste $2(\mathrm{CH}$ paste $+5 \% \mathrm{AC})]$. Cytotoxicity and potential osteogenic was performed by MTT and alkaline phosphatase activity, respectively, after 1, 3 and 7 days. Results: For intergroups comparisons, ANOVA 2 factors were used, followed by Tukey test $(\mathrm{p}<0.05)$. There was no difference among the pastes for cytotoxicity in both cells $(\mathrm{p}>0.05)$. For osteogenic potential, it was found that all experimental groups stimulated mineralization in relation to control group, except for experimental paste 2 at 7 days. Conclusion: The addition of AC to the $\mathrm{CH}$ paste does not modify toxicity and osteogenic properties. Add $10 \%$ of AC appears to be more effective than $5 \%$.
\end{abstract}

Keywords: Alkaline phosphatase; Calcium hydroxide; Charcoal; Endodontics.

\section{Resumo}

Objetivos: O objetivo deste estudo foi avaliar a citotoxicidade e o potencial osteogênico de medicamentos experimentais contendo Hidróxido de Cálcio (HC) e Carvão Ativado (CA). Metodologia: Células osteoblásticas (MC3T3) e fibroblásticas (L929) foram cultivadas em placas de 96 poços $\left(1 \mathrm{x} 10^{4}\right.$ células / poço) e, após 24 h, tratadas com extratos, de acordo com os grupos experimentais [(Grupos experimentais: $\mathrm{C}-\mathrm{Controle}$; $\mathrm{CH}-\mathrm{pasta} \mathrm{HC}$; $\mathrm{HC}+10 \% \mathrm{CA}$ - pasta experimental 1 (pasta $\mathrm{HC}+10 \% \mathrm{CA}) ; \mathrm{HC}+5 \% \mathrm{CA}$ - pasta experimental $2($ pasta $\mathrm{HC}+5 \%$ CA)]. Citotoxicidade e potencial osteogênico foram realizados por Atividade do MTT e da fosfatase alcalina, respectivamente, após 1, 3 e 7 dias. Resultados: Para as comparações intergrupos, foram utilizados os fatores ANOVA 2 , seguido do teste de Tukey $(\mathrm{p}<0,05)$. Não houve diferença entre as pastas para citotoxicidade em ambas as células 
( $p>0,05)$. Para o potencial osteogênico, verificou-se que todos os grupos experimentais estimularam a mineralização em relação ao grupo controle, exceto a pasta experimental 2 aos 7 dias. Conclusão: A adição de CA na pasta HC não altera a toxicidade e as propriedades. A adição de $10 \%$ de CA parece ser mais eficaz do que $5 \%$.

Palavras-chave: Fosfatase alcalina; Hidróxido de cálcio; Carvão vegetal; Endodontia.

\begin{abstract}
Resumen
Objetivos: El objetivo de este estudio fue evaluar la citotoxicidad y el potencial osteogénico de medicamentos experimentales que contienen Hidróxido de calcio (HC) y Carbón activado CA. Metodología: Se cultivaron células osteoblásticas (MC3T3) y fibroblásticas (L929) en placas de 96 pocillos (1 x $10^{4}$ células / pocillo) y, a las 24 h, se trataron con extractos, según grupos experimentales [(Grupos experimentales: C - Control; HC - pasta $\mathrm{HC} ; \mathrm{HC}+10 \%$ $\mathrm{CA}$ - pasta experimental 1 (pasta $\mathrm{HC}+10 \% \mathrm{CA}$ ); $\mathrm{HC}+5 \% \mathrm{CA}-$ pasta experimental 2 (pasta $\mathrm{HC}+5 \% \mathrm{CA}$ )] $\mathrm{La}$ citotoxicidad y potencial osteogénico fue realizada por Actividad de MTT y fosfatasa alcalina, respectivamente, después de 1, 3 y 7 días. Resultados: Para las comparaciones intergrupales se utilizaron factores ANOVA 2, seguido de la prueba de Tukey ( $\mathrm{p}<0.05)$. No hubo diferencia entre las pastas para la citotoxicidad en ambas células ( $\mathrm{p}>0.05)$. Para el potencial osteogénico, se encontró que todos los grupos experimentales estimularon la mineralización en relación al grupo control, excepto la pasta experimental 2 a los 7 días. Conclusión: La adición de CA a la pasta HC no modifica la toxicidad y propiedades Agregar un 10\% de AC parece ser más efectivo que un 5\%.
\end{abstract}

Palabras clave: Fosfatasa alcalina; Hidróxido de calcio; Carbón vegetal; Endodoncia.

\title{
1. Introduction
}

Calcium hydroxide $(\mathrm{CH})$ is considered one of the gold standard materials in dentistry (Carvalho, et al., 2020; Reddy, et al., 2020; Victorino, et al., 2021) and has many adequate properties, including biocompatibility, antimicrobial action, high $\mathrm{pH}$, osteogenic potential, capacity of diffusion in dentin, and stimulation apical and periapical tissues repair. These properties were justified and widely described by its mechanism of action (Estrella, et al., 1995) as an ionic dissociation and release of hydroxyl ions that determine the strong alkalinity, as well, the strong antibacterial action and anti-inflammatory action. The dissolution of dentin mineral is prevented by alkaline $\mathrm{pH}$ and it inactivate the lactic acid and also activates alkaline phosphatases enzyme (Estrella, et al., 1995; Reddy et al., 2020). These aspects justify its wide use as medication in endodontic (Mohammadi \& Dummer, 2011; Hilton, et al., 2013; Labban, et al., 2014; Pereira, et al., 2019). Nevertheless, some disadvantages are observed, such as solubility in contact with oral environment (Hilton, et al., 2013), and limited or no action against some microorganisms present in secondary and/or persistent endodontic infections, especially on Enterococcus faecalis (E. faecalis) and Candida albicans (C. albicans) (Mohammadi \& Dummer, 2011).

Different materials were added in $\mathrm{CH}$ pastes to improve their characteristics, as non-steroidal anti-inflammatory and antibiotic agents (da Silva, et al., 2020;), chlorhexidine (Souza-Filho, et al., 2008; Saatchi, et al., 2014), dichloroisocyanurate (Chan, et al.,2020), zinc oxide (Tanomaru-Filho, et al., 2015) and iodoform nanoparticles (Garrocho-Rangel, et al., 2021) and activated charcoal (AC) (Elfaramawy, 2021). The mechanism of action consists in adsorption capacity of different toxic substances (Ballini, et al., 2019; Gao, et al., 2019). It is also capable of removing a wide variety of organic, inorganic and metal contaminants, reduce the products to be absorbed, besides it has stability and a high surface area (Sugumaran, et al., 2012; Ballini, et al., 2019). AC has antimicrobial action on E. Faecalis (Kim, et al., 2009) and C. Albicans (Saravanan, et al., 2016) and adequate biological properties (Illingworth, et al., 2012).

Considering the limited action of $\mathrm{CH}$ in persistent endodontic infections caused by E. faecalis and C. albicans, the addition of $\mathrm{AC}$ in $\mathrm{CH}$ pastes for intracanal usage could be indicated. However, since the literature in this field is very incipient, different concentrations of experimental pastes were idealized. In addition, analysis of the interaction between materials and cells is an important criterion for the evaluation of new dental materials and in vitro tests are the first step in this process. Therefore, before clinical indications, it is necessary to verify some actions of experimental pastes, as the cytotoxicity and the bioactivity, whereas these aspects can interfere on apical and periapical tissues repair (Mohammadi \& Dummer, 2011; Oliveira, et al., 2013). 
The choice of cells for this kind of analysis is also important, and they should mimic to the maximum the clinical situation in which the material is used. Since an intracanal medications comes in contact with the periapical tissues, its effects on fibroblasts and osteoblasts should be evaluated using cell lines that should have physiological and adhesive properties similar to those of human fibroblasts and. osteoblasts. Several established and immortalized strains of fibroblasts and. osteoblasts are commercially available, among which we can mention the L929 and MC3T3-E, respectively.

Therefore, the aim of present study was to evaluate the cytotoxicity and the osteogenic potential from two experimental medications containing $\mathrm{CH}$ and $\mathrm{AC}$, testing the hypothesis that the addition of $\mathrm{AC}$ in different concentrations does not change the properties of conventional $\mathrm{CH}$ paste, considering the cytotoxicity and osteogenic potential.

\section{Methodology}

\section{Cell cultures}

Two 2 cells cultures was used: Mouse pre-osteoblastic cell line MC3T3-E1 subclone 14 (American Type Culture Collection, VA), cultivated in growth media (GM) Alpha-Minimum Essential Media ( $\alpha$-MEM) (Gibco, USA) supplemented with $10 \%$ fetal bovine serum (FBS), (Sigma Life Science, USA) and 1\% antibiotic and antimycotic (Gibco, USA); L929 fibroblastic cells (Mouse conjunctive tissue - ATCC CCL-1 NCTC) (Adolfo Luiz Institute - SP, Brazil) cultivated in GM Minimum Essential Media (MEM) (Gibco, Glasgow, UK) supplemented with 10\% FBS and 1\% antibiotic and antimycotic. Both cultures were kept at $37^{\circ} \mathrm{C}$, in a humidified atmosphere containing $5 \% \mathrm{CO}_{2}$ and $95 \%$ air. After subconfluence, cultures were subcultured and plated in 96-well culture plates at a cell density of 1x10 4 cells/well L929 were cultivate in GM and MC3T3 cultured in osteogenic medium (OM), which was GM supplemented with $5 \mu \mathrm{g} / \mathrm{mL}$ ascorbic acid (Sigma-Aldrich, Brazil) and $7 \mathrm{mmol} / \mathrm{L} \mathrm{b}$-glycerophosphate (Sigma-Aldrich, MO).

\section{Experimental medications}

The medias, GM for L929 and OM for MC3T3 were exposed during 24h to experimental groups: Group C: Negative control (culture media); Grupo $\mathrm{CH}$ : $\mathrm{CH}$ standard paste, containing $1 \mathrm{~g}$ of pure $\mathrm{CH}$ (Biodinâmica, Lobato, PR, Brazil) and $1 \mathrm{~mL}$ of saline solution (Samtec, Lagoinha, SP, Brazil), representing the $\mathrm{CH}$ paste commonly used in endodontic treatments, Group $\mathrm{CH}+10 \% \mathrm{AC}$ : Experimental gr, composed by $0.9 \mathrm{~g}$ of pure $\mathrm{CH}$ (Biodinâmica), $0.1 \mathrm{~g}$ of powdered AC (Natuvita, Palhoça, SC, Brazil) $(\mathrm{CH}+10 \% \mathrm{AC})$ and $1 \mathrm{~mL}$ of saline solution (Samtec); and Group CH+5\%AC: Experimental paste 2, composed of 0.95 $\mathrm{g}$ of pure $\mathrm{CH}$ (Biodinâmica), $0.05 \mathrm{~g}$ of $\mathrm{AC}$ (Natuvita) and $1 \mathrm{ml}$ of saline solution (Samtec) $(\mathrm{CH}+5 \% \mathrm{AC})$. As a positive control, 35\% hydrogen peroxide (Synth, Diadema, SP, Brazil), used only for methodology validation. Ratio extraction was established at $0.2 \mathrm{~g} / \mathrm{mL}$ according to ISO 10993-12 (ISO E. Biological evaluation of medical devices-Part 12: Sample Preparation and reference materials. 2012). The extraction media was collected and filtered with sterile $0.22 \mu \mathrm{m}$ pore diameter filters, and different concentrations (undiluted, 1/2 and 1/4) were prepared for cytotoxicity experiments, for osteogenic potential evaluation, only pure extracts (100\%) were used. All experiments were carried out in triplicate, according to the ISO 10993-5 (ISO, Standardization IOf. ISO 10993-5: Biological evaluation of medical devices-Part 5: Tests for in vitro cytotoxicity. ISO Geneva; 2009).

\section{Cytotoxicity test}

The cytotoxicity test was performed with fibroblastic $\left(5^{\text {th }}\right.$ passage $)$ and osteoblastic cells $\left(20^{\text {th }}\right.$ passage $)$ at 1,3 and 7 days, and the cell viability was evaluated by the colorimetric method Thiazolyl blue tetrazolium bromide (MTT). This assay is dependent on the reduction of MTT (Sigma, St. Louis, MO, USA) in formazan, by mitochondrial viable cells dehydrogenase, 
which can be quantified by spectrophotometry (Mosmann, 1983). It is a quantitative method used to evaluate cytotoxicity, proliferation and activation of viable cells with high precision. Aliquots of MTT at $5 \mathrm{mg} / \mathrm{ml}$ in phosphate buffered saline solution (PBS; Gibco) were prepared and the primary cultures were then incubated with 10\% solution in culture media for 4 hours at $37 \mathrm{oC}$, in a humidified atmosphere containing $5 \% \mathrm{CO}_{2}$.

After this period, the entire solution from was removed and $100 \mu \mathrm{L}$ of dimethyl sulfoxide solution (DMSO) was added to each well under stirring for 5 minutes for complete solubilization of the precipitate formed. The colorimetric measurement was performed on a spectrophotometer (SpectraCount - Packard Instrument Company, USA) using a wavelength of $570 \mathrm{~nm}$.

\section{Osteogenic potential test}

To evaluate the osteogenic potential, alkaline phosphatase activity (ALP) was performed in osteoblastic cell cultures on days 1, 3 and 7 using the biochemical method. ALP activity was quantitatively assessed by releasing thymolphthalein by hydrolysis of the thymolphthalein monophosphate substrate, using a commercial kit (Labtest Diagnostic SA, Belo Horizonte, MG, Brazil), following the manufacturer's instructions.

Blank, standard and tests tubes were used. Initially, proteins were extracted from each well with $0.1 \%$ sodium lauryl sulfate (Sigma, Aldrich, USA) for $30 \mathrm{~min}$. In all tubes, $5 \mu \mathrm{L}$ of substrate and $50 \mu \mathrm{L}$ of $0.3 \mathrm{mmol} / \mathrm{mL}$ diethanolamine buffer with $\mathrm{pH} 10.1$ were added. In standard tube, $5 \mu \mathrm{L}$ of standard solution was added. The tubes were kept at $37^{\circ} \mathrm{C}$ for $2 \mathrm{~min}$. Then, $5 \mu \mathrm{L}$ of cell lysate from each well was added to each test tube and kept at $37^{\circ} \mathrm{C}$ for $10 \mathrm{~min}$. After this period, $200 \mu \mathrm{L}$ of reagent color $\left(\mathrm{Na}_{2} \mathrm{CO}_{3} 0.09 \mu \mathrm{mol} / \mathrm{mL}\right.$ and $\left.\mathrm{NaOH} 0.25 \mu \mathrm{mol} / \mathrm{mL}\right)$ were added to all tubes (blank, standard and tests) and absorbance was measured in a spectrophotometer using a wavelength of $590 \mathrm{~nm}$ ( $\mu$ Quanti, BioTek Instruments, Inc., Winooski, VT, USA).

ALP activity, in $\mu \mathrm{mol}$ of thymolphthalein/mL, was calculated from the standard tube measurement and normalized by total protein content determined by modified Lowry method (de Oliva, et al., 2009). For this, the proteins extracted with $0.1 \%$ sodium lauryl sulfate (ThermoFisher Scientific) were mixed with Lowry's solution (ThermoFisher Scientific) (1:1) for $20 \mathrm{~min}$ at room temperature. The extract was diluted in Folin and Ciocalteau phenol reagent (ThermoFisher Scientific) for $30 \mathrm{~min}$. The absorbance was read in a spectrophotometer using a wavelength of $680 \mathrm{~nm}$.

\section{Statistical analysis}

Cell viability values were expressed in percentage in relation to group C (negative control). ALP was calculated from the standard tube measurement and normalized by the total protein content. Normality of errors of the data was verified by the tests of Shapiro-Wilk. The significance level was set at 5\%. The significance of differences among groups were assessed by two-way analysis of variance test (ANOVA two-way), followed by post-hoc Tukey test. GraphPad Prism 7 (GraphPad Software).

\section{Results}

After evaluate the fibroblast cells, no difference was observed among three pastes, after 1 (Figure 1A) and 3 days (Figure 1B) of treatment, regardless of the dilution (without dilution, 1/2 and 1/4); however, after 7 days (Figure 1C), group $\mathrm{CH}+5 \% \mathrm{AC}$ significantly reduced cell viability when compared to group $\mathrm{CH}+10 \% \mathrm{AC}(\mathrm{p}<0.05)$ (Figure $1-\mathrm{A}, \mathrm{B}$ and $\mathrm{C}$ ) at the undiluted extract. In relation to control group (group C), it is possible to verify a reduction in cell viability in three evaluated times in pure extracts $(\mathrm{p}<0.05)$ (Figure 1). Considering the dilution of $1 / 2$, there was difference among groups $\mathrm{CH}+10 \% \mathrm{AC}$ 
and $\mathrm{C}$ after 3 (Figure 1B)- and 7-days treatment ( $\mathrm{p}<0.05$ ) (Figure 1C). And no difference was detected in 1/4 dilution.

To osteoblastic cells, after 1 day (Figure 1D), no difference was detected in viability among the three evaluated pastes, regardless of their dilution. Pure extracts (without dilution) were different from group C, presenting relative cytotoxicity. Considering 1/4 dilutions, after 1 day, there was no significant difference between groups $\mathrm{C}$ and $\mathrm{CH}$. At the 1/2 dilution, no cytotoxicity, with similar results to the control group (Figure 1D). At 3 days (Figure 1E), all pastes without dilution were cytotoxic when compared to control group. Considering the dilutions of $1 / 2$ and $1 / 4$, a difference was detected between groups $\mathrm{C}$ and $\mathrm{CH}$. After 7 days, all extracts were considered cytotoxic, regardless of the dilution of the extract (Figure 1F).

Figure 1.Average and standard deviation of cell viability (percentage in relation to group C) of L.929 cells treated for 1 (A), 3 (B) and 7 days (C); MC3T3 cells treated for 1 day (D), 3 days $(\mathrm{E})$ and 7 days (F) with different concentrations of calcium hydroxide paste (group $\mathrm{CH}$ ), experimental paste 1 (group $\mathrm{CH}+10 \% \mathrm{AC}$ ) and 2 (group $\mathrm{CH}+5 \% \mathrm{AC}$ ) and the control group (group $\mathrm{C}$ ). The asterisk (") indicates a statistically significant difference $(p<0.05)$ in relation to group I (ANOVA 2 Factors)
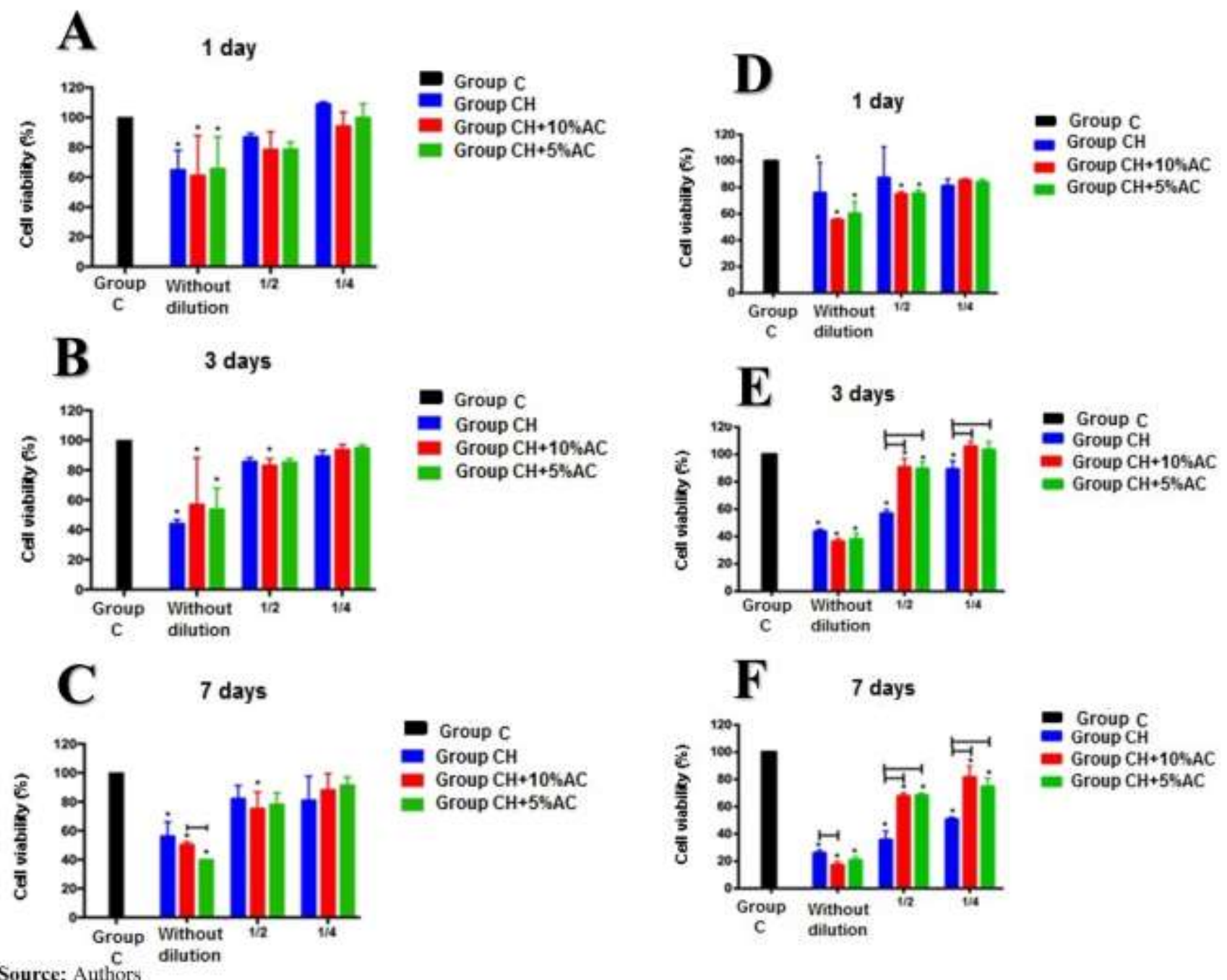

Regarding the osteogenic potential, after 1 and 3 days, there was no significant difference between the three evaluated pastes. At 7 days of treatment, there was a reduction in the inducing potential for group $\mathrm{CH}+5 \% \mathrm{AC}$ in relation to groups $\mathrm{CH}$ and $\mathrm{CH}+10 \% \mathrm{AC}$. When comparing the results of experimental pastes with group $\mathrm{C}$, it can be seen that the analyzed pastes were different from control $(\mathrm{p}<0.05)$, showing bioactivity, with exception of group $\mathrm{CH}+5 \% \mathrm{AC}$ at 7 days (p>0.05) (Figure 2). 
Figure 2. Average and standard deviation of the alkaline phosphatase activity at 1,3 and 7 days, comparing calcium hydroxide paste (group (HC), experimental paste 1 (group $\mathrm{CH}+10 \% \mathrm{AC}$ ) and 2 (group $\mathrm{CH}+5 \% \mathrm{AC}$ ) and the control group (group C), Letters $a$ and $b$ indicate statistically significant differences in relation to group $C$ (ANOVA 2 factors).

\section{ALP}

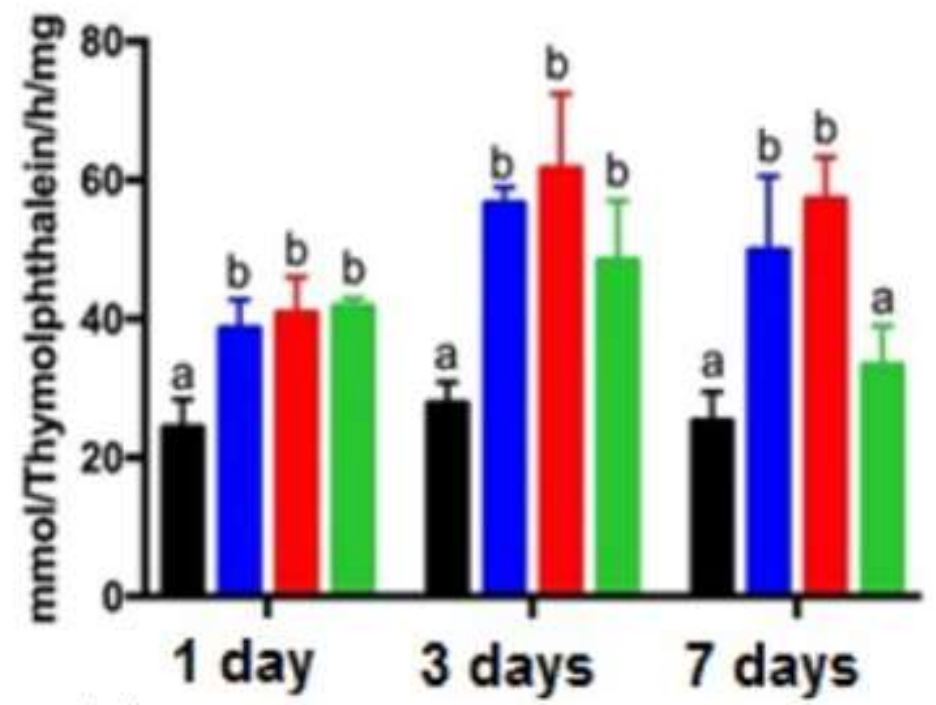

aroup C aroup HC - Group $\mathrm{HC}+10 \% \mathrm{AC}$ - Group $\mathrm{HC}+5 \% \mathrm{AC}$

Source: Authors

\section{Discussion}

The hypothesis of the study was confirmed, since the addition of activated charcoal to the conventional calcium hydroxide paste did not significantly change its properties. The cell lines used in the present study was determinant to verify similarly action to the adjacent tooth tissues as would be occur in in vivo studies.

Regarding osteogenic potential, it was found that experimental paste $1(\mathrm{CH}+10 \% \mathrm{AC})$ was similar to $\mathrm{CH}$ paste, unlike experimental paste $2(\mathrm{CH}+5 \% \mathrm{AC})$, which had its potential reduced at 7 days.

The analysis of biological properties is important to endodontic medications, due those medications must reduce the pathogenic microorganisms without damage the apical and periapical cells and tissues (Correa, et al., 2009; Carvalho, et al., 2018; da Silva, et al., 2020). Cytotoxicity tests are performed to assess biocompatibility of materials and understand metabolism and repair process (Correa, et al., 2009; Lim, et al., 2017). MTT assay is based on the ability of living cells to convert yellow salt tetrazolium for lilac formazan crystals, being a simple, fast, accurate and with high reproducibility test (Correa, et al., 2009; Carvalho, et al., 2018). In present study was observed CH pastes are not cytotoxic, and literature agree, being the most used intracanal medications in endodontics (Desai \& Chandler, 2009; Mohammadi \& Dummer, 2011; Althumairy, et al., 2014). Even investigating different substances, da Silva, et al. (2020) showed that $\mathrm{CH}$ pastes with 5\% sodium diclofenac, ibuprofen or amoxicillin presented low cytotoxicity in 1, 2, 3 and 7 days and different concentrations, corroborating the results of this study, which obtained low cytotoxicity results, and that can be justified by the presence of calcium hydroxide in its compositions on both studies. The test periods were chosen to understand the action of the components in initial analyzes, and long periods with cell culture are not recommended due to the limitations involving this type of study (Silva, et al., 2020).

Calcium hydroxide paste dissociates into calcium ions and hydroxyl ions when it fills the main root canal; these ions diffuse through the dentinal tubules, and the concentrations are different in root canal and apical and periapical tissues (Mohammadi \& Dummer, 2011). In view of this, assessing cell viability in contact with different concentrations becomes 
necessary. Additionally, studies have already shown that cell proliferation can be altered over time (Correa, et al., 2009; Pires, et al., 2016), which makes it pertinent to evaluate different time points. In present study, differences were found in relation to cellular viability at different experimental times and concentrations (dilutions), demonstrating that the cytotoxicity is directly proportional to the time of exposure of cells to experimental pastes.

Correa, et al. (2009) observed that the pure extract (without dilution) of endodontic sealers containing calcium hydroxide associated with oily vehicles significantly reduces the cell viability of THP-1 monocytes significantly after 24 hours of treatment (Correa, et al., 2009). The authors demonstrated that the paste calcium hydroxide only stop significantly reducing cell viability at dilutions below $1 \%$; a fact that corroborates the findings of our study, in which the pure extracts of the three pastes significantly reduced the cell viability of fibroblasts and osteoblastic cells at all times evaluated.

In this context, Labban, et al. (2014) suggest that the ability of calcium hydroxide to promote proliferation or prevent cell death is concentration-dependent, so that its dissolution is shown as an alternative to possible negative effects and favours pulp healing (Labban, et al., 2014). This property of preventing cell death was also observed in the present study, since $\mathrm{CH}$ paste did not reduce cell viability. Otherwise, adding $\mathrm{AC}$ has not increased the cytotoxicity of the conventional $\mathrm{CH}$ paste already used in dental clinic.

Another important point to be discussed refers to the evaluation of cell bioactivity through ALP, which allows to verify the potential to induce formation of mineralized tissue. The alkaline phosphatase is a biochemical marker linked to the membrane, which is secreted by osteoblasts (Modareszadeh, et al., 2012). Chen et al. (2016) should that $\mathrm{CH}$ has osteogenic potential using the ALP staining assay as in our study (Chen, et al., 2016). The bioactive of $\mathrm{CH}+10 \% \mathrm{AC}$ was higher than $\mathrm{CH}+5 \% \mathrm{AC}$; we believe the characteristics of AC can improve the osteogenic potential, since that the ALP was bigger in experimental paste with more AC.

It is important to emphasized that this is an initial study, and cytotoxicity and osteogenic potential are only some of the wide ranges of properties expected in a biomaterial in development. The present results encourage further experimental studies to evaluate properties such as tooth discoloration, antimicrobial actions, anti-inflammatory effect and biocompatibility in animals, in addition to clinical trials, in order to prove the effectiveness of these news experimental medications in dental clinical practice. These results suggest a dose-dependent cytotoxic effect of all evaluated pastes; however, the addition of AC to the $\mathrm{CH}$ paste does not modify toxicity-related properties. Regarding bioactivity, experimental paste $1(\mathrm{CH}+10 \% \mathrm{AC})$ showed greater activity than paste $2(\mathrm{CH}+5 \% \mathrm{AC})$.

Despite of the limitations of the present study, the aspects investigated influence on apical and periapical tissues repair, and they are fundamental to clinical therapy. The results of the present study support the idea of new experimental medications, and to future clinical indication, it is essential to analyse antimicrobial action of new medication, mainly, for use in teeth with pulp necrosis and apical periodontitis. Thus, studies analysing the direct contact with microbial biofilms, effect on biofilm present in dentinal tubules must be made. After that, in vivo studies must be made to confirm the use of new medication.

\section{Final Considerations}

The addition of $\mathrm{AC}$ to the $\mathrm{CH}$ paste does not modify toxicity and the osteogenic properties. Add $10 \%$ of AC appears to be more effective than $5 \%$. Thus, studies analysing the direct contact with microbial biofilms, effect on biofilm present in dentinal tubules in different concentrations must be made. 


\section{Acknowledgments}

The authors thank São Paulo Research Foundation (FAPESP) - Process 2018/16356-2 and Coordination for the Improvement of Higher Education Personnel - Brazil (CAPES), for the financial support.

\section{References}

Althumairy, R. I., Teixeira, F. B., \& Diogenes, A. (2014). Effect of dentin conditioning with intracanal medicaments on survival of stem cells of apical papilla. J. Endod, 40(4):521-5. https://doi.org/10.1016/j.joen.2013.11.008

Ballini, A., Cantore, S., Saini, R., Pettini, F., Fotopoulou, E. A., Saini, S. R., Georgakopoulos, I. P., Dipalma, G., Gargiu lo Isacco, C., \& Inchingolo, F. (2019). Effect of activated charcoal probiotic toothpaste containing Lactobacillus paracasei and xylitol on dental caries: a randomized and controlled clinical trial. Journal of biological regulators and homeostatic agents, 33(3), 977-981.

Carvalho, G. A. O., de Almeida, R. R., Câmara, J. V. F., \& Pierote, J. J. A. (2020). Hidróxido de cálcio versus hibridização em capeamentos pulpares: revisão de literatura. Research, Society and Development, 9(7), e244974069-e244974069. http://dx.doi.org/10.33448/rsd-v9i7.4069

Carvalho, N. C., Guedes, S., Albuquerque-Júnior, R., de Albuquerque, D. S., de Souza Araújo, A. A., Paranhos, L. R., Camargo, S., \& Ribeiro, M. (2018). Analysis of Aloe vera cytotoxicity and genotoxicity associated with endodontic medication and laser photobiomodulation. Journal of photochemistry and photobiology. B, Biology, 178, 348-354. https://doi.org/10.1016/j.jphotobiol.2017.11.027

Chan, W., Chowdhury, N. R., Sharma, G., Zilm, P., \& Rossi-Fedele, G. (2020). Comparison of the biocidal efficacy of sodium dichloroisocyanurate and calcium hydroxide as intracanal medicaments over a 7-day contact time: an ex vivo study. Journal of Endodontics, 46(9), 1273-1278. https://doi.org/10.1016/j.joen.2020.05.011

Chen, L., Zheng, L., Jiang, J., Gui, J., Zhang, L., Huang, Y., Chen, X., Ji, J. \& Fan, Y. (2016). Calcium Hydroxide-induced Proliferation, Migration, Osteogenic Differentiation, and Mineralization via the Mitogen-activated Protein Kinase Pathway in Human Dental Pulp Stem Cells. J. Endod, 42(9):1355-61. https://doi.org/10.1016/j.joen.2016.04.025

Correa, G. T. B., et al (2009). Cytotoxicity evaluation of two root canal sealers and a commercial calcium hydroxide paste on THP1 cell line by Trypan Blue assay. Journal of Applied Oral Science, 17(5), 457-461. https://dx.doi.org/10.1590/S1678-77572009000500020

da Silva, G. F., Cesário, F., Garcia, A., Weckwerth, P. H., Duarte, M., de Oliveira, R. C., \& Vivan, R. R. (2020). Effect of association of non-steroidal antiinflammatory and antibiotic agents with calcium hydroxide pastes on their cytotoxicity and biocompatibility. Clinical oral investigations, 24(2), 757-763. https://doi.org/10.1007/s00784-019-02923-y

de Oliva, M. A., Maximiano, W. M., de Castro, L. M., da Silva, P. E., Jr, Fernandes, R. R., Ciancaglini, P., Beloti, M. M., Nanci, A., Rosa, A. L., \& de Oliveira, P. T. (2009). Treatment with a growth factor-protein mixture inhibits formation of mineralized nodules in osteogenic cell cultures grown on titanium. The journal of histochemistry and cytochemistry: official journal of the Histochemistry Society, 57(3), 265-276. https://doi.org/10.1369/jhc.2008.952713

Desai S, Chandler N. (2009). Calcium hydroxide-based root canal sealers: a review. J Endod.35(4):475-80. 10.1016/j.joen.2008.11.026.

Elfaramawy, M. (2021). The Effect Of The Addition Of Activated Charcoal To Different Formulations Of Calcium Hydroxide On Their Effect On The Fracture Resistance Of Endodontically Treated Teeth. Egyptian Dental Journal, 67(2), 1629-1623. 10.21608/edj.2021.48721.1325

Estrela, C., Sydney, G. B., Bammann, L. L., \& Felippe Junior, O. (1995). Mechanism of the action of calcium and hydroxy ions of calcium hydroxide on tissue and bacteria. Braz Dent J, 6(2): 85-90. http://143.107.206.201/bdj/t0262.html

Gao, Y., Wang, G., Li, Y., Lv, C., \& Wang, Z. (2019). Effects of oral activated charcoal on hyperphosphatemia and vascular calcification in Chinese patients with stage 3-4 chronic kidney disease. Journal of nephrology, 32(2), 265-272. https://doi.org/10.1007/s40620-018-00571-1

Garrocho-Rangel, A., Escobar-García, D. M., Gutiérrez-Sánchez, M., Herrera-Badillo, D., Carranco-Rodríguez, F., Flores-Arriaga, J. C., \& Pozos-Guillén, A. (2021). Calcium hydroxide/iodoform nanoparticles as an intracanal filling medication: synthesis, characterization, and in vitro study using a bovine primary tooth model. Odontology, 1-9. https://doi.org/10.1007/s10266-021-00591-7

Giongo, M, Santos, R. A. M. dos, Maciel, S. M, Fracasso, M. L. C, \& Victorino, F. R. (2017). Analysis of pH and release of calcium of association between melaleuca alternifolia oil and calcium hydroxide. Revista de Odontologia da UNESP, 46(2), 104-108. Epub March 13, 2017.https://doi.org/10.1590/18072577.07816

Hilton, T. J., Ferracane, J. L., Mancl, L., \& Northwest Practice-based Research Collaborative in Evidence-based Dentistry (NWP) (2013). Comparison of $\mathrm{CaOH}$ with MTA for direct pulp capping: a PBRN randomized clinical trial. Journal of dental research, 92(7), 16S-22S. https://doi.org/10.1177/0022034513484336

Illingworth, J. M., Rand, B., Williams, P. T. (2012). Novel activated carbon fibre matting from biomass fibre waste. Proceedings of the Institution of Civil Engineers-Waste and Resource Management, 165(3):123-132. https://doi.org/10.1680/warm.12.00001

ISO E. Biological evaluation of medical devices-Part 12: Sample Preparation and reference materials. 2012.

ISO, Standardization IOf. ISO 10993-5: Biological evaluation of medical devices-Part 5: Tests for in vitro cytotoxicity. ISO Geneva; 2009.

Kim, H. C., Park, S.J., Lee, C. G., Kim, S. B., Kim, K. W. (2009). Bacterial attachment to iron-impregnated granular activated carbon. Colloids Surf. B: Biointerfaces, 74(1):196-201. https://doi.org/10.1016/j.colsurfb.2009.07.018 
Research, Society and Development, v. 10, n. 5, e26010514671, 2021

(CC BY 4.0) | ISSN 2525-3409 | DOI: http://dx.doi.org/10.33448/rsd-v10i5.14671

Labban, N., Yassen, G. H., Windsor, L. J., \& Platt, J. A. (2014). The direct cytotoxic effects of medicaments used in endodontic regeneration on human dental pulp cells. Dental traumatology, 30(6), 429-434. https://doi.org/10.1111/edt.12108

Lim, M.J., Jang, H.J., Yu, M.K., Lee, K.W., Min, K.S. (2017). Removal efficacy and cytotoxicity of a calcium hydroxide paste using N-2-methyl-pyrrolidone as a vehicle. Restor Dent Endod, 42(4):290-300. https://doi.org/10.5395/rde.2017.42.4.290

Modareszadeh, M. R., Di Fiore, P. M., Tipton, D. A., \& Salamat, N. (2012). Cytotoxicity and alkaline phosphatase activity evaluation of endosequence root repair material. Journal of endodontics, 38(8), 1101-1105. https://doi.org/10.1016/j.joen.2012.04.014

Mohammadi, Z., \& Dummer, P. M. (2011). Properties and applications of calcium hydroxide in endodontics and dental traumatology. International endodontic journal, 44(8), 697-730. https://doi.org/10.1111/j.1365-2591.2011.01886.x

Mosmann T. (1983). Rapid colorimetric assay for cellular growth and survival: application to proliferation and cytotoxicity assays. Journal of immunological methods, 65(1-2), 55-63. https://doi.org/10.1016/0022-1759(83)90303-4

Oliveira, I. R., Andrade, T. L., Jacobovitz, M., \& Pandolfelli, V. C. (2013). Bioactivity of calcium aluminate endodontic cement. Journal of endodontics, 39(6), 774-778. https://doi.org/10.1016/j.joen.2013.01.013

Pereira, T. C., da Silva Munhoz Vasconcelos, L. R., Graeff, M., Ribeiro, M., Duarte, M., \& de Andrade, F. B. (2019). Intratubular decontamination ability and physicochemical properties of calcium hydroxide pastes. Clinical oral investigations, 23(3), 1253-1262. https://doi.org/10.1007/s00784-018-2549-0

Pires, C. W., Botton, G., Cadoná, F. C., Machado, A. K., Azzolin, V. F., da Cruz, I. B., Sagrillo, M. R., \& Praetzel, J. R. (2016). Induction of cytotoxicity, oxidative stress and genotoxicity by root filling pastes used in primary teeth. International endodontic journal, 49(8), 737-745. https://doi.org/10.1111/iej.12502

Reddy, S., Prakash, V., Subbiya, A., \& Mitthra, S. (2020). 100 Years of Calcium Hydroxide in Dentistry: A Review of Literature. Indian Journal of Forensic Medicine \& Toxicology, 14(4), 1203.

Saatchi, M., Shokraneh, A., Navaei, H., Maracy, M. R., \& Shojaei, H. (2014). Antibacterial effect of calcium hydroxide combined with chlorhexidine on Enterococcus faecalis: a systematic review and meta-analysis. Journal of Applied Oral Science, 22(5), 356-365. http://dx.doi.org/10.1590/1678-775720140032

Saravanan, A., Kumar, P.S., Devi, G.K., Arumugam, T. (2016). Synthesis and characterization of metallic nanoparticles impregnated onto activated carbon using leaf extract of Mukia maderasapatna: Evaluation of antimicrobial activities. Microb. Pathog, 97:198-203. https://doi.org/10.1016/j.micpath.2016.06.019

Souza-Filho, F. J. de, et al (2008). Antimicrobial effect and $\mathrm{pH}$ of chlorhexidine gel and calcium hydroxide alone and associated with other materials. Brazilian Dental Journal, 19(1), 28-33. https://doi.org/10.1590/S0103-64402008000100005

Sugumaran, P., Susan, V. P., Ravichandran, P., \& Seshadri, S. (2012). Production and characterization of activated carbon from banana empty fruit bunch and Delonix regia fruit pod. J Sustainable Energy \& Environment, 3(3):125-32.

Tanomaru-Filho, M., Guerreiro-Tanomaru, J. M., Faria, G., Aguiar, A. S., \& Leonardo, R. T. (2015). Antimicrobial activity and ph of calcium hydroxide and zinc oxide nanoparticles intracanal medication and association with chlorhexidine. The journal of contemporary dental practice, 16(8), 624-629. DOI: $10.5005 /$ jp-journals-10024-1732

Victorino, F. R., Rocha, I. S., de Oliveira Lazarin, R., Seron, M. A., Sivieri-Araujo, G., \& Almeida, R. S. (2021). Maxillary Canine with two roots and two canals: A case report. Research, Society and Development, 10(2). DOI: http://dx.doi.org/10.33448/rsd-v10i2.12599 